RESEARCH NOTE

\title{
Potential of the antifungal activity of Ageratina riparia (Regel) R. M. King and H. Rob. against banana anthracnose disease caused by the fungus, Colletotrichum musae
}

\author{
R.M.N.D. Ratnayake, B.M.R. Bandara ${ }^{1}$, N.K.B. Adikaram ${ }^{2}$, D.S.A. Wijesundara ${ }^{3}$ and V. Karunaratne ${ }^{1, *}$ \\ ${ }^{1}$ Department of Chemistry, University of Peradeniya, Peradeniya, Sri Lanka \\ ${ }^{2}$ Department of Botany, University of Peradeniya, Peradeniya, Sri Lanka \\ ${ }^{3}$ National Institute of Fundamental Studies, Hanthana Road, Kandy, Sri Lanka
}

Received:29/03/2018; Accepted:11/05/2018

\begin{abstract}
Ageratina riparia (Regel) R.M. King and H. Rob. of the family Asteraceae is an invasive weed distributed widely in the montane regions of the Central Province of Sri Lanka. The present study was carried out to investigate the antifungal components of the weed, $A$. riparia and their ability to control banana anthracnose disease caused by the fungus, Colletotrichum musae. The methanol extract of the aerial part of $A$. riparia was subjected to activity guided fractionation and methylripariochromene A was isolated as the bioactive compound. The effectiveness of the methanol extract of $A$. riparia against banana anthracnose disease was assessed and a promising reduction of the anthracnose lesions was observed specially at high concentrations. Brine shrimp micro-well cytotoxicity assay was carried out for the methanol extract, and the commercial fungicide Bavistin FL. Cytotoxicity of the commercial fungicide was much higher ( $100 \%$ mortality at $250 \mathrm{ppm})$ compared to the methanol extract and methylripariochromene A. Thus, the aerial part of $A$. riparia can be commercially exploited as a natural alternative to commercially available fungicides for its ability to control banana anthracnose disease.
\end{abstract}

Keywords: Ageratina riparia, invasive weed, antifungal activity, methanol extract, methylripariochromene A, banana anthracnose disease, Colletotrichum musae.

\section{INTRODUCTION}

During plant co-evolution with their respective environments for millions of years, the secondary metabolites they produced played a vital role in their adaptations to insect and microbial attacks. This allowed plants to live in a state of dynamic equilibrium with its environment. However, some plant species use their bioactivities to become noxious weeds and transform the environment around them. Sri Lanka is a plant biodiversity hot spot with $25 \%$ of its flowering plants being endemic. Sri Lankan plants have been tested for biological activity with promising results (Hewage et al., 1997). In addition, the structural diversity among Sri Lankan higher and lower plants are typified by the discovery of alkaloids, (Puvenendran et al., 2008), compounds with iron chelating function (Kathirgmanathar et al., 2006; Karunaratne et al., 1992; Karunaratne et al., 2005; Tezuka et al., 1994;
Bandara et al., 1990), phenolic acids, ketones (Thadhani et al., 2012; Thadhani et al., 2010), five-membered ring butenolides and hydrazulenones (Piers and Karunaratne, 1984; Carr et al., 2012) all of them have been shown to possess a variety of biological activities. However, there is a paucity of studies on the chemistry and biological activity of Sri Lankan noxious weeds. Invasion by exotic weed species is a serious threat to natural ecosystems. Attempts have been made to search for efficient methods to reduce the abundance of noxious weeds for many years (Bhattacharjee et al., 2009). In addition to the chemistry of indigenous plants, studying the chemical constituents of invasive weeds might also point to their potential commercial uses.

Ageratina riparia (Regel) R. M. King and H. Rob. of the family, Asteraceae is an invasive weed that is widespread in tropical and warm temperate regions. It is native to New Mexico and West Indies and today is widespread in many regions in the world. It has become a noxious invader in the up-country, wet zone of Sri Lanka, invading many natural and man-made ecosystems.

Methylripariochromene A (1), ripariochromene A (2), ripariochromene B (3), ripariochromene C (4) and eupatoriochromene (5) have been isolated from Australian species of $A$. riparia, while acetovanillochromene (6) has been isolated from Jamaican species. Taraxasterol, taraxasteryl acetate, taraxasteryl palmitate, epi-friedelinol and sigmasterol has been reported from Indian $A$. riparia (Taylor \& Wright, 1971; Banerjee et al., 1985). Methylripariochromene A isolated from Sri Lankan $A$. riparia showed antifungal activity against Cladosporium cladosporioides, Aspergillus sp., Fusarium sp., Collectrichumgloeosporioides and Cercospora nicotianae (Bandara et al., 1992).

\section{Postharvest pathology of banana}

In banana, postharvest losses are encountered during ripening and storage. Specifically, anthracnose, crown rot and finger rot are the main diseases that result in the loss of quality and quantity of banana at postharvest level. Anthracnose disease is reported in all banana producing 
<smiles>[R9]c1c(C(C)=O)cc2c(c1OC)OC(C)(C)C=C2</smiles>

(1) $\mathrm{R}=\mathrm{CH}_{3}$

(2) $\mathrm{R}=\mathrm{H}$<smiles>CC(=O)c1cc2c(cc1O)OC(C)(C)C=C2</smiles>

(5)<smiles>[R]CC(=O)c1cc2c(cc1O)OC(C)(C)C=C2</smiles>

(3) $\mathrm{R}=\mathrm{OCOCH}_{3}$

(4) $\mathrm{R}=\mathrm{OCH}_{2} \mathrm{CH}\left(\mathrm{CH}_{3}\right)_{2}$<smiles>COc1cc(C(C)=O)cc2c1OC(C)(C)C=C2</smiles>

Figure 1: Chromenes isolated from A. riparia.

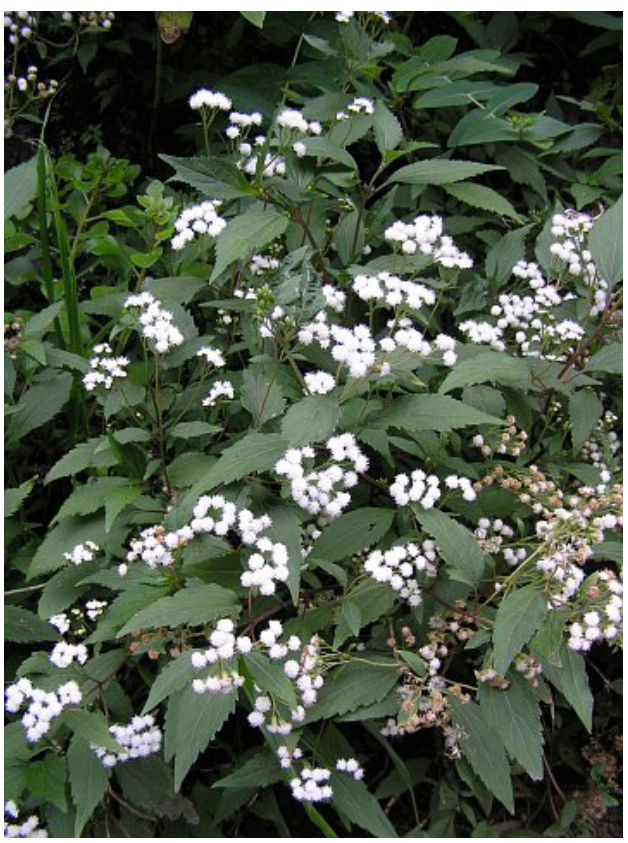

Figure 2: The habit of Ageritina riparia.

countries and the disease results in unmarketable fruits due to lesions on the peel. This disease can be seen in many banana varieties in Sri Lanka such as embul, kolikuttu, ambun and anamalu, where the causative agent is the fungus, Colletotrichum musae. Anthracnose is commonly seen as a finger blemish or rot of ripening bananas. Lensshaped to circular, slightly sunken brown spots appear on the skin. With time, the spots turn black, enlarge and merge.

Bavistin FL is a commonly used broad spectrum commercial fungicide against the anthracnose disease of banana. However, the use of fungicides on banana fruits after harvest is not acceptable to consumers and may be hazardous to human health. As such, there is an urgent need to develop alternative approaches, such as plant extracts, for safe and efficient control of postharvest diseases. The work described herein, reports on the control of anthracnose disease in banana using antifungal compounds present in the weed $A$. riparia.

\section{MATERIALS AND METHODS}

\section{Collection and preparation of plant material}

Mature plant material (5 kg) of $A$. riparia was collected from Hakgala and identified by the Royal Botanic Gardens, Peradeniya (Figure 2).

\section{Preparation of the methanol extract}

Air dried, processed aerial parts of $A$. riparia (374 g) were extracted with hot methanol by using a Soxhlet apparatus. 
The extract obtained was evaporated to dryness at $30{ }^{\circ} \mathrm{C}$ using a rotary evaporator. The crude extract was further dried using a freeze drier to obtain $80 \mathrm{~g}$ of the methanol extract.

\section{Isolation of the antifungal active principle}

Methanol extract $(5 \mathrm{~g})$ of the aerial part was made into a slurry with silica gel and subjected to MPLC on silica gel using solvent combinations of increasing polarity of dichloromethane and methanol. Antifungal activity of fractions were assessed by the TLC bioassay technique (Klarman and Sanford, 1968) using the fungus, Cladosporium cladosporioides. Antifungal compound containing fraction $1(0.5 \mathrm{~g})$ obtained from MPLC column was subjected to gravity column chromatography using ethyl acetate: hexane (2:8) as the eluent to yield an oily, brownish colored compound (12 mg) with antifungal activity which was isolated and identified as methylripariochromene A (6-acetyl-7, 8-dimethoxy-2, 2-dimethylchromene) (Bandara et al., 1992).

\section{Assessment of antifungal activity}

A series of concentrations (1000, 500, 250, 125 and 62.5 $\mathrm{mg} / \mathrm{L}$ ) of the methanol extract, methylripariochromene A and Bavistin FL was prepared in 1:1 hexane: chloroform solution. A slide germination assay was carried out according to Anon (1943). Randomly selected conidia (about 150) were counted in each drop for germination under the optical microscope and percentage germinations were calculated.

\section{Assessment of anthracnose disease control in banana fruits}

\section{Plant material}

Banana cv. embul fruits harvested 12-13 weeks after bunch emergence were obtained from the Peradeniya market. Bunches were dehanded and washed under tap water and allowed to air dry at room temperature. Each banana hand was then separated into individual fingers. Fruits without visual defects and with uniform weight and size were sorted for use in the experiments. Fruits were then wiped with cotton wool soaked in $70 \%$ ethanol and allowed to air-dry. Finally, the cut ends of the stalks were sealed with vasline to prevent loss of moisture and fungal invasions.

\section{Assessment of the anthracnose disease control}

For assessment of activity against the banana anthracnose activity, $1000,500,250,125$ and $62.5 \mathrm{mg} / \mathrm{L}$ solutions of the methanol extract, and Bavistin FL (positive control) were prepared using tween $20(50 \mu \mathrm{L} / \mathrm{L})$ and sterile distilled water and fruits were dipped in each solution for $30 \mathrm{~s}$. Fruits treated with sterile distilled water and Bavistin FL were used as negative and positive controls respectively. In each treatment, the concentration was comprised of ten replicate fruits and separate experiments were carried out to test the effect of each concentration.

The fruits were inoculated with a conidial suspension of $C$. musae by placing three $20 \mu \mathrm{L}$ drops of the conidial suspension along the long axis of the fruit. Inoculated fruits were incubated in moist chambers at room temperature. Then the fruits were examined daily for progression of anthracnose disease. The length and width of each lesion were measured in cm using a ruler. The disease severity was recorded as average lesion area $\left(\mathrm{cm}^{2}\right)$ taking into account all inoculation sites of a particular treatment category of fruits. The following equation was used for the calculations (Abayasekara, 1998). Each experiment comprised of ten replicates.

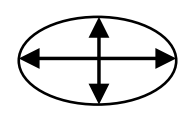

Lesion area $\left(\mathrm{cm}^{2}\right)=(\mathrm{a} / 2) \times(\mathrm{b} / 2) \times(22 / 7)$

Where,

$\mathrm{a}=$ length of the lesion $(\mathrm{cm})$

$\mathrm{b}=$ breadth of the lesion $(\mathrm{cm})$

\section{RESULTS}

Results revealed that all samples tested, methanol extract, methylripariochromene A and Bavistin FL (commercial fungicide) showed comparable activity at $250 \mathrm{~g} / \mathrm{mL}$ although at lower concentration the latter had greater potency.

From the slide germination assay data (Table 1), it was clear that although the pure compound, methylripariochromene A possessed greater antifungal activity than the crude methanol extract, in terms of a

Table 1: Percentage germination of conidia of Colletotrichum musae.

\begin{tabular}{lcccc}
\hline \multirow{2}{*}{ Treatment } & \multicolumn{4}{c}{ Concentration/mg/L } \\
\cline { 2 - 5 } & \multicolumn{4}{c}{ Percentage germination \% } \\
\cline { 2 - 5 } & SDW & 250 & 125 & 62.5 \\
\hline Methanol extract & & $0 *$ & $2 \pm 1$ & $2 \pm 2$ \\
Bavistin FL & $34 \pm 5$ & 0 & 0 & $1 \pm 2$ \\
Methylripariochromene A & & 0 & 0 & $4 \pm 4$ \\
Bavistin FL & & 0 & 0 & $1 \pm 1$ \\
& $40 \pm 6$ & & & \\
\hline
\end{tabular}

*Data of ten replicates were statistically analyzed using Minitab 14 at $95 \%$ confidence level SDW: sterile distilled water 
practical and commercial approach to harnessing the biological potential of $A$. riparia, the latter was a low cost option.

Since antifungal activity of the methanol extract was almost similar to that of methylripariochromene A, the methanol extract was used to assess the anthracnose disease control in banana fruits. Lesions were appeared on the banana fruit four days after inoculation and observations were done after that. Observations could not be performed seven days after inoculation due to the deterioration of fruits.

According to the results obtained, the methanol extract showed control of the anthracnose disease in banana, especially at the $1000 \mathrm{mg} / \mathrm{L}$ concentration (Table 1). However, the commercial fungicide (Bavistin FL) has a better ability of controlling the anthracnose disease than the mathanol extract. However, at $5000 \mathrm{mg} / \mathrm{L}$ both Bavistin FL and the methanol extract of $A$. riparia appeared equally effective in combating the anthracnose disease (Figure 3 ).

\section{Brine shrimp micro-well cytotoxicity assay}

Cytotoxicity of the methanol extract, methylripariochromene $\mathrm{A}$ and Bavistin FL was tested using the brine shrimp micro-well cytotoxicity assay. Cytotoxicity of the commercial fungicide (Bavistin FL) was very high compared to the cytotoxicity of the methanol extract and methylripariochromene A.

At $1,000 \mathrm{mg} / \mathrm{Lthe}$ methanol extract was cytotoxic ( $0 \%$ survival in the brine shrimp assay). Bavistin FL on the other hand showed $0 \%$ survival even at $250 \mathrm{mg} / \mathrm{L}$. In general, at lower concentrations $(<500 \mathrm{mg} / \mathrm{L})$, particularly

Table 2: Effect of the methanol extract of A. riparia on anthracnose development.

\begin{tabular}{|c|c|c|c|c|c|c|c|}
\hline \multirow[b]{3}{*}{ Day } & \multirow[b]{3}{*}{ Treatment } & \multicolumn{6}{|c|}{ Area of the lesion $/ \mathrm{cm}^{2}$} \\
\hline & & \multicolumn{6}{|c|}{ Concentration/ppm } \\
\hline & & $\begin{array}{c}1 \% \text { Acetone } \\
\text { in SDW }\end{array}$ & 1000 & 2000 & 3000 & 4000 & 5000 \\
\hline \multirow[t]{3}{*}{1} & & $0.88 * \pm 0.1$ & & & & & \\
\hline & Methanol extract & & $0.4 \pm 0.2$ & $0.2 \pm 0.1$ & 0 & 0 & 0 \\
\hline & Bavistin FL & & 0 & 0 & 0 & 0 & 0 \\
\hline \multirow[t]{3}{*}{2} & & $2.1 \pm 0.3$ & & & & & \\
\hline & Methanol extract & & $1.0 \pm 0.2$ & $0.4 \pm 0.1$ & $0.6 \pm 0.1$ & $0.4 \pm 0.1$ & 0 \\
\hline & Bavistin FL & & 0 & 0 & 0 & 0 & 0 \\
\hline \multirow[t]{3}{*}{3} & & $3.9 \pm 0.5$ & & & & & \\
\hline & Methanol extract & & $2.6 \pm 0.5$ & $1.4 \pm 0.3$ & $1.3 \pm 0.2$ & $0.9 \pm 0.2$ & $0.3 \pm 0.1$ \\
\hline & Bavistin FL & & 0 & 0 & 0 & 0 & 0 \\
\hline
\end{tabular}

*Data were statistically analyzed using Minitab 14 at $95 \%$ confidence level

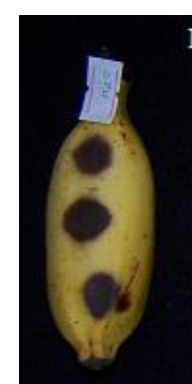

Plant extract

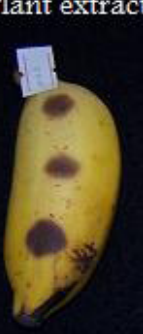

SDW

1000

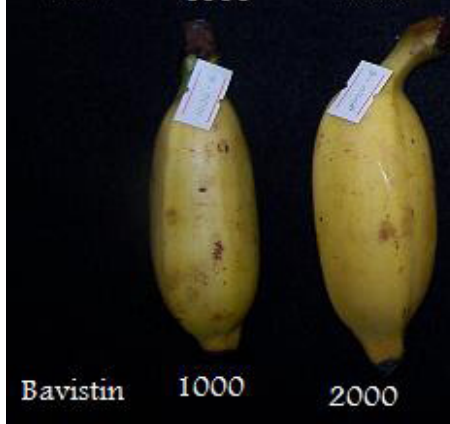

1000

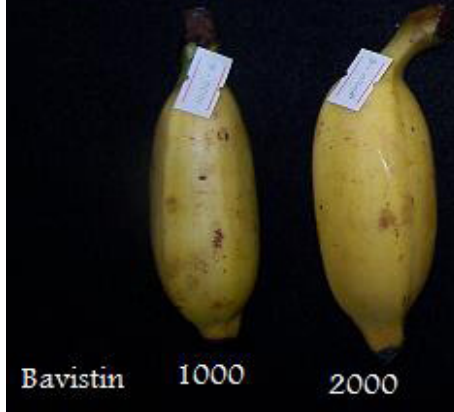

2000

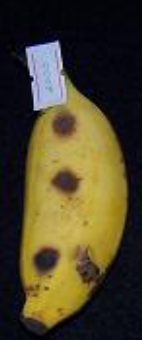

2000

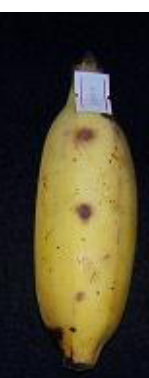

3000

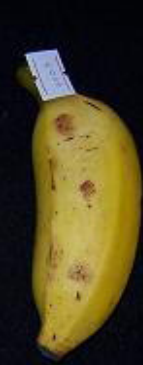

4000

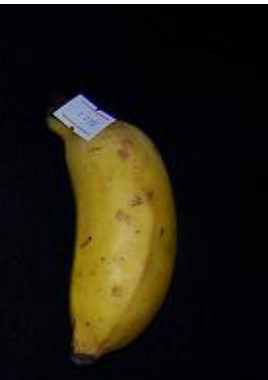

5000
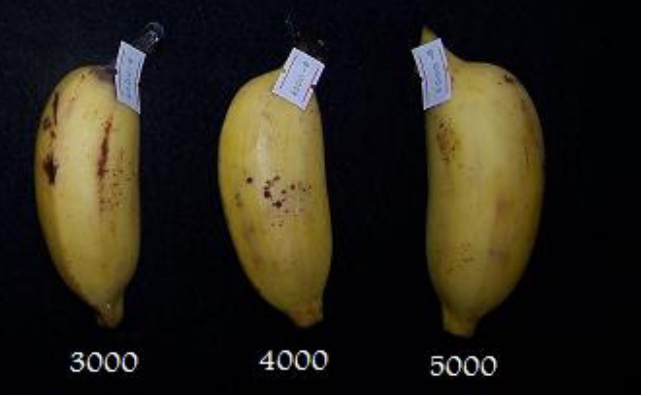

Figure 3: Anthracnose development in banana. 
Table 3: Percent survival of brine shrimps against the methanol extract of A. riparia and isolated methylripariochromene A.

\begin{tabular}{lccccccc}
\hline \multirow{2}{*}{\multicolumn{1}{c}{ Sample }} & \multicolumn{7}{c}{ Percent survival \%* } \\
\cline { 2 - 8 } & $\begin{array}{r}\mathbf{1 0 0 0} \\
\mathbf{m g} / \mathbf{L}\end{array}$ & $\begin{array}{r}\mathbf{5 0 0} \\
\mathbf{M g} / \mathbf{L}\end{array}$ & $\begin{array}{r}\mathbf{2 5 0} \\
\mathbf{M g} / \mathbf{L}\end{array}$ & $\begin{array}{c}\mathbf{1 2 5} \\
\mathbf{M g} / \mathbf{L}\end{array}$ & $\begin{array}{c}\mathbf{6 2 . 5} \\
\mathbf{m g} / \mathbf{L}\end{array}$ & $\begin{array}{c}\text { Sea } \\
\text { water }\end{array}$ \\
\hline Methanol extract & 0.00 & 10.00 & 76.66 & 100 & 100 & 100 \\
\hline Methylripariochromene A & 0.00 & 0.00 & 10.00 & 93.33 & 96.67 & 100 \\
\hline Bavistin FL & 0.00 & 0.00 & 0.00 & 0.00 & 0.00 & 100 \\
\hline
\end{tabular}

Data of three replicates were statistically analyzed using Minitab 14 at $95 \%$ confidence level

the methanol extract was less toxic. The pure antifungal compound methylripariochromene A was more toxic $(<$ 250) than the methanol extract while being less toxic than Bavistin FL.

\section{CONCLUSION}

In conclusion, A. riparia contains an antifungal active compound (methylripariochromene A) against C. musae which is the active agent against the banana anthracnose disease. Hence, the aerial part of $A$. riparia may be commercially exploited.

\section{REFERENCES}

Abayasekara, C.L. (1998). Freckle disease caused by Phyllosticta musarum in banana: biology, control and host defence responses. Ph. D. Thesis, University of Peradeniya, Sri Lanka. 295pp.

Anon, American Phytopathological Society, Committee on Standardization of Fungicidal Tests. 1943. The slide-germination method of evaluating protectant fungicides. Phytopathology 33:627-632.

Bandara, B.M.R., Hewage, C.M., Karunaratne, V., Wannigama, G.P. and Adikaram, N.K.B. (1992). An antifungal chromene from Eupatorium riparium. Phytochemistry 31 (6): 1983-1985.

Bandara, B.M.R., Hewage, C.M., Jayammane, L., Karunaratne, V., Bandara, K.A.N.P., Adikaram, N.K.B., Pinto, M.R.M. and Wijesundara, D.S.A. (1990). Biological activity of some steam distillates from ten species of Rutaceae plants, Journal of National Science Council 18(1): 71-77.

Banerjee, S., Jakupovic, J., Bohlmann, F., King, R. M. and Robinson, H. (1971). Chromenes from Ageratina riparia. Phytochemistry 24(11):2681-2683.

Bhattacharjee, J., Taylor, J. P., Smith, L. M. and Haukos, D. A. (2009). Seedling competition between native cottonwood and exotic saltcedar: implications for restoration. Biological Invasions 11: 1777-1787.

Carr,G., Ratnayake, R., Bandara,R., Wijesundara,S., Williams,D.E., Tarling, T., Balgi, A.D., Roberge, M., Karunaratne,V. and Andersen, R.J. (2012). Hydrazulenones from the genus Hortonia. Journal of Natural Products 75(6): 1189-1191.

Hewage, C.M., Bandara, K. N. A. P., Karunaratne, V., Bandara, B.M.R., and Wijesundara, D.S.A.(1997). Insecticidal activity of some medicinal plants of Sri Lanka, Journal of National Science Council 25(3): 141-
150.

Karunaratne, V., Hoveyda, H.R. and Orvig, C. (1992). General method for the Synthesis of Trishydroxamic acids. Tetrahedron Letters 33: 1827.

Karunaratne, V., Bombuwala, K., Kathirgamanathar, S. and Thadani, V. (2005). Lichens: A chemically important biota. Journal of National Science Foundation Sri Lanka 33(3): 169-186.

Kathirgamanathar, S., Ratnasooriya, W.D., Baekstrom, P., Andersen, R.J. and Karunaratne, V. (2006). Chemistry and bioactivity of physciaceae lichens: Pyxine consocians and Heterodermia Leucomelos. Pharmaceutical Biology 44: 217-220.

Klarman, W.L. and Sanford, J.B. (1968). Isolation and purification of an antifungal compound from infected soybean. Life Sciences 7:1095-1103.

Piers, E. and Karunaratne V. (1984). Methylenecyclopentane annulation: a synthesis of the sesquiterpenoid $( \pm)$-pentalenene. Journal of the Chemical Society, Chemical Communications 15: 959-960.

Puvenendran, S., Carr, G., Wickramasinghe, A., Karunaratne, D. N., Andersen, R. J. and Karunaratne, V. (2008). Antioxidant constituents of Xylopia Championii. Pharmaceutical Biology 46: 252-256.

Taylor, D. R. and Wright, J. A. (1971). Chromenes from Eupatorium riparium. Phytochemistry 10(7): 1665-1667.

Tezuka, Y., Kikuchi, T., Dhanabalasingham, B., Karunaratne, V. and Gunatilaka, A.A.L. (1994). Studies on Terpenoids and Steroids, Part 25. Complete ${ }^{\mathrm{I}} \mathrm{H}$ and ${ }^{13} \mathrm{C}$ NMR assignments of Salaciquinone, A new 7-Oxo-Quinonemethide dinortriterpenoid from Salacia reticulata. Journal of Natural Products 57(2): 270.

Thadhani, V.M., Chaudharay, M.I., Andersen, R.J. and Karunaratne, V. (2010). Novel entry into 5-decarboxydibenzofurans via Smiles rearrangement of the lichen para-depside, erythrin. Journal of Chemical Research 34(3): 154-157.

Thadhani, V.M., Choudhary, I. and Karunaratne, V. (2012). Antimicrobial activity and cytotoxicity of lichen metabolites. Journal of National Science Foundation of Sri Lanka 40(1): 43-48. 